\title{
Soil Fertility Management and Cropping System Function in Ameliorating Maize Productivity in Ethiopia
}

\author{
Derib Kifle* \\ Ethiopian Institute of Agricultural Research, Ethiopia
}

*Corresponding author: Derib Kifle, Ethiopian Institute of Agricultural Research, Ethiopia.

Received Date: January 21, 2020

Published Date: February 11, 2020

\section{Introduction}

Maize (Zea mays L.) is the most important cereal worldwide [1] that belongs to the family Poaceae. It is a C4 plant, short duration and quick growing crop. It is globally ranks the third position among cereal crops after wheat and rice and it is important staple food in many countries. Grains of maize contain 13\% moisture, $10 \%$ crude protein and 70.3 carbohydrates [2] is one of the most versatile emerging crops having wider adaptability under varied agro climatic conditions. Globally, maize is known as queen of cereals because it has the highest genetic yield potential among the cereals. Maize is cultivated throughout the world $\left(58^{\circ} \mathrm{N}\right.$ latitude to $40^{\circ} \mathrm{S}$ latitude) in an area of $179.9 \mathrm{~m}$.ha across 165 countries with a production of $1013.6 \mathrm{~m} . \mathrm{t}$ and average productivity of $5.63 \mathrm{t} / \mathrm{ha}$. Only the USA, China and Brazil contribute $63 \%$ to the global maize production whilst Mexico, Argentina, India, Ukraine, Indonesia, France, Canada and South Africa are also major maize producing countries [3].

Maize (Zea mays L.) is one of the principal food crops in Ethiopia. It is also the most important cereal crop in terms of area coverage, production, and economic importance in Ethiopia [4]. According to [5] maize occupied 2.1 million hectares (ha) of land with estimated average yield of 2.9 tons $(\mathrm{t}) \mathrm{ha}^{-1}$. This is far below the world average $5.1 \mathrm{t} \mathrm{ha}^{-1}$ [6]. In Ethiopia, bulk of maize has been grown in humid agro-ecology within the altitudinal ranges of 1500 to 1800 meters above sea level that contributes to $80 \%$ of the national maize production [7]. In this agro-ecology, pressure on land to put under cultivation has been increased in time series with raising population and following by gradual reductions of fallow periods
[8]. In addition, maize has been cultivated continuously on the same piece of land and most of these areas are characterized by cereallivestock farming systems where free grazing animals remove more of crop residues than are returned in to soils for nutrient recycling, and aggravate soil erosion and high loss of nutrients [9].

The major constraints affecting maize production and productivity are declining soil fertility and inadequate crop management practices, imbalanced nutrition, disturbed soil properties, cultivars being grown, weed infestation etc. [10]. Declining soil fertility is fundamental impediment to agricultural growth and a major reason for slow growth in maize production in sub-Saharan Africa [11]. Low soil fertility due to monoculture cereal production systems is recognized as one of the major causes for declining per capita food production [12]. Therefore, soil fertility replenishment is increasingly viewed as one of the critical to the process of poverty alleviation. This is generally true for Ethiopian agro ecologies, particularly for a dominant maize based mono cropping system of Ethiopia, which is one of the major problems leading to decline in soil fertility from time to time and resulting bottleneck for the smallholder maize producer of the country.

The use of inorganic fertilizers alone has not been helpful under intensive agriculture because it aggravates soil degradation. Maintaining and improving soil quality is crucial if agricultural productivity and environment quality are to be sustained for future generations. Intensive agriculture has had negative effects on the soil environment over the past decades (e.g. loss of soil organic matter, soil erosion and water pollution). Management 
methods that decrease requirements for agricultural chemicals are needed in order to avoid adverse environment impacts. [13]. Sustainable crop production, therefore, requires Integrated soil fertility management involving the judicious use of combinations of organic and inorganic resources is a feasible approach to overcome soil fertility constraints. Combined organic/inorganic fertilization both enhanced carbon storage in soils and reduced emissions from nitrogen fertilizer use while contributing to high crop productivity in agriculture [14].

Improved cropping system which requires integration of legume crops in maize based mono cropping areas to add N- fixed through biological nitrogen fixation or biomass retentions [15] and a careful management of all nutrients sources available in a farm, particularly in maize based cropping systems which include inorganic fertilizers, organic manures, waste materials suitable for recycling nutrients, soil reserves, are immense in boosting maize production. All most all farmers in Ethiopia produce maize as continuous mono cropping or some of them as an intercrop with food legumes using the recommended $110 \mathrm{~N} \mathrm{~kg} /$ ha and 46 $\mathrm{kg} / \mathrm{ha}$ fertilizer for maize [16]. However, the price of inorganic fertilizer is getting beyond the purchasing power of smallholder farmers because of high production cost and uncertain accessibility in addition to non-responsiveness of some soils that leads the farmers to non-benefits. Therefore, inclusion of leguminous crops in cropping systems has multiple advantages in improving and sustaining maize productivity. Intercropping offers potential advantages for resource utilization decreased inputs and increased sustainability in crop production [17]. Therefore, the chief aim of this paper is to text existing information on the response of maize to integrated use of organic and inorganic fertilizer application and improved cropping system in Ethiopia. Accordingly, a review of the major findings on the response of maize grain yield to sole and integrated use of organic and inorganic fertilizer (integrated soil fertility management) and cropping system on the productivity of maize in Ethiopia.

Table 1: The effect of green manure on maize grain yield under farmers' field and on station.

\begin{tabular}{|c|c|c|c|c|}
\hline Treatments (t/ha) & Shoboka & Walda & BRC & Mean \\
\hline Check & 2.38 & 3.12 & 3.12 & 2.87 \\
\hline Green manure & 2.7 & 6.33 & 5.2 & 4.74 \\
\hline Recommended NP $(100 / 20)$ & 5.55 & 6.48 & 5.12 & 5.72 \\
\hline Green manure + $1 / 2$ recommended NP & 4.6 & 5.6 & 5.2 & 5.14 \\
\hline Green manure + recommended NP & 3.49 & 6.09 & 7.33 & 5.77 \\
\hline Green manure $+1 / 3$ recommended NP & 4.36 & 4.88 & 3.92 & 4.39 \\
\hline $\operatorname{LSD}(5 \%)$ & 1.4 & 1.7 & 1.13 & 1.31 \\
\hline $\mathrm{CV} \%$ & 20 & 17 & 12 & 16 \\
\hline
\end{tabular}

Source: [24].

Maize yield responses to green manure: A field experiment was designed by Bako Agricultural Research Center (BARC) in three location to evaluate the possibility of replacing $\mathrm{N}$-fertilizer and long-term fallow system with Dolichos lablab green manure

\section{Plant Nutrient and Soil Fertility Management in Maize Production}

In the effort of alleviating the soil fertility problem which is one of the major causes of low productivity of maize, different research activities have been undertaken using various fertilizer sources in different parts of the country.

\section{Sole and combined Use of Organic and Inorganic Fertilizers for Maize Production}

Use of chemical fertilizers for maize production: Influence of chemical fertilizer (NP) on maize productivity in different parts of the country was reviewed and summarized by different researchers and scholars. The application of 75/33 kg N/P ha ${ }^{-1}$ around Bako and Didessa, 46/33 kg N/P ha-1 in Jimma area, 92/44 $\mathrm{kg} \mathrm{N} / \mathrm{P} \mathrm{ha}^{-1}$ in Hawassa area and 69/30 kg N/P ha- ${ }^{-1}$ in the Rift Valley were recommended for maize production [18]. Accordingly, the combined application of 90/15 kg N/P ha ${ }^{-1}$ fertilizers recommended for vertisols of around Aykel, Chilga district in North Gondar zone had improved maize grain yield (5.36 t ha-1) and yield components [19]. Similarly, [20] found that a combined application of NP gave a better grain yield of hybrid maize (BH-140) and improved $\mathrm{P}$ content of the soil. Higher grain yield of maize variety (Melkassa I), 3,868 and 5,069 $\mathrm{kg} \mathrm{ha}^{-1}$ in Babile and Dire Dawa area were obtained with the combined application of $64 / 20 \mathrm{~kg} \mathrm{NP} \mathrm{ha}^{-1}$ [21]. The application of 69-20-75 kg N-P-K ha-1 for maize gave significantly higher yields compared to another recommended NP at Areka [22]. The minimum $\left(4,687 \mathrm{~kg} \mathrm{ha}^{-1}\right)$ and maximum $\left(4,905 \mathrm{~kg} \mathrm{ha}^{-1}\right)$ maize yield at Dangla in 2009 cropping season were obtained from control and $100 \mathrm{~kg} \mathrm{K2} 0 \mathrm{ha}^{-1}$, respectively [23]. Similarly, at Mota, [23] found that the minimum $\left(2,951 \mathrm{~kg} \mathrm{ha}^{-1}\right)$ and maximum $\left(3,929 \mathrm{~kg} \mathrm{ha}^{-1}\right)$ yield of maize in the 2008 cropping season were recorded from the control and application of $100 \mathrm{~kg} \mathrm{~K} 2 \mathrm{O} \mathrm{ha}^{-1}$, respectively. The mean grain yield of maize at both locations responded non-significantly to the applied $\mathrm{K}$ rates [23]. 
revealed that green manuring provided comparable grain yield to that of the recommended NP fertilizers on marginal soil fertility status like BRC and Walda. Similarly, green manure of sole legumes could substitute for more than $70 \mathrm{~kg}$ urea $\mathrm{N} \mathrm{ha}^{-1}$ at Jimma. Moreover, the application of Sesbania sesban's biomass and dry FYM above 5 $\mathrm{t} \mathrm{ha}^{-1}$ gave comparable or greater mean maize yield of up to $69 \mathrm{~kg} \mathrm{~N}$ $\mathrm{ha}^{-1}$ from urea fertilizer [24].

Farmyard manure and NP: Field observation and on-farm experiments conducted recently in Yabello district of the Borana, southern Ethiopia showed that maize responded positively to farmyard manure application. All treatments recorded significantly higher grain and stover yield of maize than did the control treatment that received no nutrient inputs (Table 2). The highest grain and stover yields were achieved where micro-doses of manure were combined with micro-fertilizer, followed by the recommended dose of fertilizers. Application of $70 \mathrm{~g}$ (corresponding to 3.71 tons per ha) of manure, combined with a small quantity ( $0.5 \mathrm{~g}$ per pocket) of fertilizer, improved maize grain yield by $77 \%$ compared to non- use of inputs [25]. Additionally, manure applied alone yielded $51 \%$ of grain compared to the control (Table 2). Despite variation between treatments, the observed significant yield improvements compared to the usual non-use of manure shows considerable scope for increasing yields of these marginal lands by using manure. As long-term research strategy on locally available sources of organic fertilizers, a strategy was designed on a continuous basis for replenishing the degraded physic-chemical properties of soils to make sustainable maize production in Bako areas and similar locations. Accordingly, a study carried out on combined uses of NP and FYM at five on farms sites indicated that integrated application is better than application either NP or FYM alone (Table 3). While previous studies at the same location revealed that FYM has to be applied every three years at the rate of $16 \mathrm{t} \mathrm{ha}^{-1}$ supplemented by $\mathrm{NP}$ fertilizer annually at the rate of 20-46 N- $\mathrm{P}_{2} \mathrm{O}_{5} \mathrm{~kg} \mathrm{ha}^{-1}$ (Table 3) for sustainable maize production around Bako and similar areas [26]. The sole application of FYM at the rates of $4-12 \mathrm{t} \mathrm{ha}^{-1}$ is also encouraging for resource poor farmers on relatively fertile soils [27].

Table 2: Yield responses of maize for manuring in Borana, southern Ethiopia.

\begin{tabular}{|c|c|c|}
\hline Treatment & Grain yield $\left(\mathrm{kg} \mathrm{ha}^{-1}\right)$ & Stover yield (kg ha-1) \\
\hline Control & $701.00+46$ & $2013.82 \pm 95$ \\
\hline Recommended practice (mineral fertilizer) & $1231.12 \pm 46 \mathrm{bc}$ & $3181.58 \pm 95 b$ \\
\hline Manure micro-dose (3.71ton ha-1 $)$ & $1015.00 \pm 46 a$ & $2684.87 \pm 95 a$ \\
\hline 5 ton of manure ${ }^{\dagger}$ & $1059.00^{ \pm} 46 \mathrm{ab}$ & $2546.49 \pm 95 a$ \\
\hline 5 ton of manure + legume intercrop & $929.70^{ \pm} 46 \mathrm{a}$ & $2572.15^{ \pm} 95 \mathrm{a}$ \\
\hline Manure micro-dose + fertilizer micro-dose & $1240.60^{ \pm} 46 c$ & $3386.62 \pm 95 b$ \\
\hline Manure micro-dose + legume intercrop & $1015.60 \pm 46 a$ & $2564.69 \pm 95 a$ \\
\hline LSD & 186.2 & 386.91 \\
\hline $\mathrm{p}$-value & 0 & 0 \\
\hline
\end{tabular}

Source: [25]. Standard errors are given by signs ' $\pm \dagger$ : equivalent to $35.45 \mathrm{~kg}$ of N ha -1. Means within a column with different or no letters are significantly different $(p<0.05)$.

Table 3: Effects of NP and FYM on maize yield at five sites around Bako, 1997.

\begin{tabular}{|c|c|c|c|c|c|c|}
\hline N/P kg ha' + FYM t ha-1 & BRC & Walda & Shoboka & Harato & Laga Kalla & Mean \\
\hline \multicolumn{7}{|c|}{ Grain Yield t ha ${ }^{-1}$} \\
\hline $0 / 0+0$ & 0.9 & 4.68 & 4.44 & 5.79 & 1.86 & 3.53 \\
\hline $0 / 0+4$ & 3.61 & 6.68 & 6.43 & 7.72 & 4.37 & 5.76 \\
\hline $0 / 0+8$ & 4.87 & 6.5 & 6.52 & 5.74 & 4.41 & 5.61 \\
\hline $0 / 0+12$ & 5.05 & 6.71 & 6.95 & 6.78 & 4.17 & 5.93 \\
\hline $20 / 20+0$ & 3.79 & 6.7 & 6.88 & 6.2 & 4.75 & 5.66 \\
\hline $20 / 20+4$ & 4.69 & 7.44 & 7.82 & 6.96 & 3.27 & 6.04 \\
\hline $20 / 20+8$ & 6.5 & 6.88 & 7.44 & 8.94 & 4.35 & 6.82 \\
\hline $20 / 20+12$ & 6.5 & 5.76 & 6.52 & 7.28 & 4.75 & 6.16 \\
\hline $40 / 25+0$ & 4.33 & 6.12 & 6.7 & 9.06 & 4.46 & 6.13 \\
\hline $40 / 25+4$ & 5.05 & 5.71 & 8 & 6.78 & 4.66 & 6.04 \\
\hline $40 / 25+8$ & 5.96 & 7.98 & 7.64 & 7.57 & 5.67 & 6.96 \\
\hline $40 / 25+12$ & 5.96 & 6.88 & 7.44 & 6 & 5.44 & 6.34 \\
\hline
\end{tabular}




\begin{tabular}{|c|c|c|c|c|c|c|}
\hline $60 / 30+0$ & 4.51 & 6.52 & 6.52 & 7.68 & 5.04 & 6.06 \\
\hline $60 / 30+4$ & 5.77 & 7.05 & 7.47 & 7.68 & 4.67 & 6.53 \\
\hline $60 / 30+8$ & 7.4 & 6.52 & 6.88 & 7.34 & 5.85 & 6.8 \\
\hline $60 / 30+12$ & 6.78 & 7.8 & 7.64 & 9.58 & 6.61 & 7.68 \\
\hline LSD & 1.24 & 1.86 & Ns & 2.02 & 1.32 & 0.72 \\
\hline
\end{tabular}

Source: [40] BRC= Bako Research Center, NS= non-significant difference at $5 \%$ probability level.

Compost and NP: A field experiment was conducted to evaluate the integrated use of compost and low rates of NP fertilizers under farmers' conditions in four different locations at Bako, western Ethiopia in 2001 cropping season. The statistical analysis for each location revealed significant differences ( $\mathrm{P} £$ 0.05) among the treatments on the maize grain yield. The difference in the grain yields of maize between and within location and cropping season as affected by applied compost and NP fertilizers were statistically significant $(\mathrm{P}<0.05)$. The statistical analysis at each location and the combined statistical analysis over locations indicated that there were significant $(\mathrm{P}<0.05)$ differences among the treatments on grain yield where the highest marginal rate of return of $213.2 \%$ and $135.8 \%$ was recorded from 55/10 kg of N/P + 5 tons ha-1 of compost and 25/11 kg of N/P +5 tons ha- ${ }^{-1}$, respectively (Table 4). Therefore, use of five tons ha-1 of compost with $55 / 10 \mathrm{~kg}$ of N/P ha-1 is found economical for maize production in Bako Tibe district and other similar areas in western regions [27].

Table 4: Effects of applied compost and NP fertilizers on the grain yield ( $t$ ha-1) of maize under different locations and cropping seasons.

\begin{tabular}{|c|c|c|c|c|c|c|c|c|}
\hline \multirow{2}{*}{ N/P (kg ha $\left.{ }^{-1}\right)+$ Compost $\left(\mathrm{t} \mathrm{ha}^{-1}\right)$} & \multicolumn{2}{|c|}{ BRC } & \multicolumn{2}{c|}{ Kejo } & \multicolumn{2}{c|}{ Anno } & DD & Mean \\
\cline { 2 - 9 } & 2000 & 2001 & 2000 & 2001 & 2000 & 2001 & 2001 & \\
\hline $0 / 0+0$ & $3970 \mathrm{c}$ & $4080 \mathrm{~b}$ & $1750 \mathrm{c}$ & $5590 \mathrm{c}$ & $3610 \mathrm{~d}$ & $3860 \mathrm{~d}$ & $4920 \mathrm{~d}$ & $3970 \mathrm{e}$ \\
\hline $0 / 0+5$ & $4460 \mathrm{bc}$ & $6440 \mathrm{a}$ & $3100 \mathrm{bc}$ & $7580 \mathrm{~b}$ & $4460 \mathrm{c}$ & $4990 \mathrm{c}$ & $6660 \mathrm{c}$ & $5380 \mathrm{~d}$ \\
\hline $25 / 11+5$ & $5240 \mathrm{abc}$ & $6440 \mathrm{a}$ & $4590 \mathrm{ab}$ & $8600 \mathrm{ab}$ & $5590 \mathrm{~b}$ & $5770 \mathrm{bc}$ & $8150 \mathrm{~b}$ & $6340 \mathrm{c}$ \\
\hline $55 / 10+5$ & $6330 \mathrm{a}$ & $7650 \mathrm{a}$ & $3820 \mathrm{~b}$ & $8410 \mathrm{ab}$ & $6780 \mathrm{a}$ & $6230 \mathrm{~b}$ & $8940 \mathrm{~b}$ & $6880 \mathrm{~b}$ \\
\hline $110 / 20+0$ & $5910 \mathrm{ab}$ & $7070 \mathrm{a}$ & $5850 \mathrm{a}$ & $8840 \mathrm{a}$ & $6450 \mathrm{a}$ & $7250 \mathrm{a}$ & $10590 \mathrm{a}$ & $7420 \mathrm{a}$ \\
\hline LSD (5\%) & 1490 & 2240 & 1870 & 1100 & 670 & 900 & 1400 & 470 \\
\hline CV\% & 15.31 & 18.75 & 25.99 & 7.46 & 6.61 & 8.49 & 8.54 & 13.09 \\
\hline
\end{tabular}

Source: [27]. BRC = Bako Research Center, DD = Dambi Dima, means within a column followed by the same letter(s) are not significantly different at 0.05 level

NP with biogas effluent: A trial was executed on uses of biogas effluent as organic fertilizer with integration of NP rates at Bako. The biogas effluent brought significant change in chemical composition of the soil in particular, soil organic carbon was fairly increased. After application the integration of both fertilizers was observed to produce significantly higher grain yield (Table 5). Although $12 \mathrm{t}$ $\mathrm{ha}^{-1}$ biogas effluents alone gave higher yields that were comparable to other treatments, biogas effluent applied at $8 \mathrm{t} \mathrm{ha}^{-1}$ with $55 / 10 \mathrm{~kg}$ $\mathrm{NP} \mathrm{ha}^{-1}$ was selected as the best alternative fertilizer combination and thus, recommended for maize production in Bako areas. The integration of biogas slurry and NP fertilizer produced significantly higher grain yield of maize and improved soil physico-chemical properties. Biogas slurry at $8 \mathrm{t} \mathrm{ha}^{-1}$ with $50 \%$ recommended N/P $\mathrm{kg} \mathrm{ha}^{-1}\left(100 / 50 \mathrm{~kg} \mathrm{ha}^{-1}\right.$ of urea/DAP) or $12 \mathrm{t}$ biogas slurry ha-1 alone was recommended for maize production [28].

Field trials with an objective to enhance low soil fertility of Haramaya soil types through integrated uses of crop residue and NP fertilizers were conduct at Haramaya on Rare experimental field from 1988-1994. Recommended fertilizers rates for Haramaya series, 133/20 kgha-1 NP and for Haramaya black clay, 128/65 kgha-
${ }^{1} \mathrm{NP}$ were tested at these full doses and one-half of both doses for each respective soil types using maize variety, EAH-75 as a test crop. Maize residues at five ton per hectare were chopped into pieces of $5-10 \mathrm{~cm}$ and incorporated to soil during dry periods. According to the result of this study, applications of the full recommended doses of NP fertilizers integrated with $5 \mathrm{t}$ per hectare crop residue were advised to improve the fertility of these soils for sustainable maize production in Haramaya area [29]. Results across season and soil types showed that yearly application of NP fertilizers at both onehalf and full recommended rates resulted in grain yield increases of more than 500 and $1100 \mathrm{kgha}^{-1}$, respectively over application of only crop residue (Table 6). Moreover, grain yield responses due to residual NP fertilizers applied only during the first year were found to be comparable to the yearly application of these fertilizers. Though seasonal rainfall trends governed maize yield response to fertilizers, Haramaya series generally gave higher grain yield than Haramaya Black clay. Thus, on both soil types of Haramaya, yearly application of the full recommended doses of NP fertilizers integrated with five ton per hectare crop residue are advised to improve the fertility of these soils for sustainable maize production in the area 
Table 5: Combined effects of biogas effluent and NP fertilizer rates on grain yield of maize at Bako.

\begin{tabular}{|c|c|c|c|c|}
\hline \multirow{2}{*}{ BE ha-1 t ha- ${ }^{-1}$ and NP rates $\mathrm{kg} \mathrm{ha}^{-1}$} & \multicolumn{4}{|c|}{ Grain Yield (kg/ha) } \\
\hline & 2001 & 2002 & 2002 & Mean \\
\hline $4 \mathrm{t} \mathrm{BE} \mathrm{ha}^{-1}+50 \% \mathrm{RR} \mathrm{NP} \mathrm{kg} \mathrm{ha}^{-1}$ & 8998 & 6741 & 2668 & 6135 \\
\hline 4 t BE ha $^{-1}+75 \%$ RR NP kg ha ${ }^{-1}$ & 9609 & 6623 & 3154 & 6462 \\
\hline $4 \mathrm{t} \mathrm{BE} \mathrm{ha}^{-1}+100 \mathrm{RR}^{\mathrm{NP}} \mathrm{kg} \mathrm{ha}^{-1}$ & 9568 & 7556 & 2812 & 6645 \\
\hline $8 \mathrm{t} \mathrm{BE} \mathrm{ha}^{-1}+50 \% \mathrm{RR} \mathrm{NP} \mathrm{kg} \mathrm{ha}^{-1}$ & 9837 & 7846 & 4357 & 7346 \\
\hline $8 \mathrm{t} \mathrm{BE} \mathrm{ha}^{-1}+75 \% \mathrm{RR} \mathrm{NP} \mathrm{kg} \mathrm{ha}^{-1}$ & 9061 & 8204 & 3575 & 6947 \\
\hline 8 t BE ha ${ }^{-1}+100 \%$ RR NP kg ha ${ }^{-1}$ & 9662 & 7628 & 3698 & 6996 \\
\hline 12 t BE ha' $a^{-1} 50 \%$ RR NP kg ha' & 9549 & 7821 & 3326 & 6899 \\
\hline 12 t BE ha $^{-1}+75 \%$ RR NP kg ha- ${ }^{-1}$ & 9389 & 7537 & 3709 & 6878 \\
\hline 12 t BE ha $^{-1}+100 \%$ RRNP kg ha-1 & 9923 & 9395 & 4187 & 7835 \\
\hline $12 \mathrm{t} \mathrm{BE} \mathrm{ha}^{-1}$ & 9216 & 7840 & 5131 & 7396 \\
\hline RR NP kg ha-1 $(110 / 20)$ & 9894 & 6265 & 2051 & 6070 \\
\hline $16 \mathrm{t} \mathrm{BE} \mathrm{ha}^{-1}$ & 8332 & 9023 & 4664 & 7340 \\
\hline LSD & 1126 & 2106 & 1503 & NS \\
\hline
\end{tabular}

Source: [33], BE (Biogas effluent), RRNP (recommended rate of nitrogen and phosphorus).

Table 6: Across season mean grain yield and correlation coefficient ( $r$ ) between rainfalls and mean maize grain yield.

\begin{tabular}{|c|c|c|c|c|}
\hline \multirow{2}{*}{ Treatments } & \multicolumn{2}{|c|}{ Haramaya Series (Typic Ustorthent) } & \multicolumn{2}{c|}{ Haramaya Black Clay (Ttypic Pellustert) } \\
\cline { 2 - 5 } & Grain Yield, kg/ha & Rainfall x Yield (r) & Grain Yield, kg/ha & Rainfall x Yield (r) \\
\hline CRYA & $2269 \mathrm{~d}$ & $0.89^{*}$ & $1611 \mathrm{c}$ & $0.63^{*}$ \\
\hline CR + HRRNPYA & $2709 \mathrm{bc}$ & $0.90^{*}$ & $2158 \mathrm{~b}$ & $0.82^{*}$ \\
\hline CR + FRRNPYA & $3115 \mathrm{a}$ & $0.97^{*}$ & $2917 \mathrm{a}$ & $0.91^{*}$ \\
\hline CRYA + HRRNPO & $2555 \mathrm{c}$ & $0.86^{*}$ & $1845 \mathrm{c}$ & $0.63^{*}$ \\
\hline CRYA + FRRNPO & $2835 \mathrm{~b}$ & $0.89^{*}$ & $2153 \mathrm{~b}$ & $0.77^{*}$ \\
\hline
\end{tabular}

Source: [29], CR (crop residue), YA (yearly application), HRR (one-half recommended rate), FRR (full recommended rate), NP (nitrogen and phosphate) $\mathrm{O}$ (only first year) and * (significantly correlated at P0.05).

At Hawassa, integrated uses of coffee by product and $\mathrm{N}$ fertilizer were evaluated to enhance low soil fertility and produce information on low input maize cropping system. Combinations of different rates of coffee by product and $\mathrm{N}$ rates were tested in maize-common bean intercropping system. Significant increment of grain yield of maize was obtained where nine ton per hectare coffee residue without $\mathrm{N}$ fertilizer applied. The same treatment had yield advantage of $91 \%$ over the control (Table 7). While $\mathrm{N}$ fertilizer alone accounted for $149 \%$ yield advantage over the control. Likewise, combinations of coffee by product and nitrogen had greater yield advantage up to $213 \%$ over the untreated control [30] Application of $\mathrm{N}$ fertilizer raised the uptake of $\mathrm{N}$ up to $60 \mathrm{~kg}$ $\mathrm{ha}^{-1}$. Therefore, coffee growers in southern region can sustain their maize production system through integrated uses of $90 \mathrm{~kg} \mathrm{~N}^{-1}$ with six-ton ha-1 coffee by product.

\section{Integrated fertilizer management on maize production}

Response to compost, green manure and NP fertilizers: Different proportions of inorganic fertilizers, compost and Tithonia biomass were tested on-farm using hybrid maize (variety: $\mathrm{BH}$
660) as the test crop with RCB design on three location in OmoNada district of Jimma zone, South Western Ethiopia. The results of the experiments generally indicated superior performance ISFM treatments to the sole application of recommended inorganic NP fertilizers in two of the three locations in the first year (Table 8). The study has successfully demonstrated that integrated fertilizer management practices gave similar amount of grain yield to that of the full NP recommendation on acidic nitosols of the region [31]. Combined application of 50\% recommended NP with $50 \%$ compost gave $5 \%$ higher yield than the sole application of inorganic NP fertilizers. In addition, application of $50 \%$ Tithonia biomass in combination with $50 \%$ recommended NP gave the same yield as the application of the full dose of the recommended nitrogen and phosphorous fertilizers for the area. The yield advantage of ISFM treatments over the recommended inorganic NP and the control ranged from 3-22 and 72-154\%, respectively. Integrated use of inorganic fertilizers and organic sources of plant nutrients has therefore, shown remarkable potential for efficient nutrient supply in maize based cropping systems on acidic nitosols of Southwestern Ethiopia. 
Table 7: Effect of coffee by product and $\mathrm{N}$ fertilizer on grain yield (kg ha-1) of intercropped maize

\begin{tabular}{|c|c|c|c|c|c|}
\hline Coffee by product $\left(\mathbf{t ~ h a}^{-1}\right)$ & N fertilizer $\left(\mathbf{k g ~ h a}^{-1}\right)$ \\
\hline & 0 & 30 & 60 & 30 & Mean \\
\hline 0 & 1541 & 3540 & 3911 & 3244 & $3259 \mathrm{~b}$ \\
\hline 3 & 2237 & 3600 & 1985 & 3866 & $3177 \mathrm{~b}$ \\
\hline 6 & 2800 & 3289 & 2755 & 4133 & $3737 \mathrm{a}$ \\
\hline 9 & 3807 & 3348 & 3659 & $3822 \mathrm{a}$ & \\
\hline Mean & $2596 \mathrm{~d}$ & $3444 \mathrm{~b}$ & $3077 \mathrm{c}$ & \multicolumn{2}{c|}{} \\
\hline
\end{tabular}

Source: [30], same letters denote no significant difference between treatments $(P>0.05)$.

Table 8: Effect of soil fertility management on grain yield of maize.

\begin{tabular}{|c|c|c|c|}
\hline \multirow{2}{*}{ Treatments } & \multicolumn{3}{|c|}{ Yield (kg haG1 yearG1 ) } \\
\cline { 2 - 4 } & Site 1 (Burka) & Site 2 (Wenji) & Site 3 (Waktola) \\
\hline 50\% recommended NP+50\% compost & 4643.7 & 4504.8 & 3936.8 \\
\hline Recommended NP & 4772.8 & 4471.1 & 3239.4 \\
\hline 50\% Tithonia biomass +50\% recommended NP & 3683 & 4684.3 & 2294.9 \\
\hline Control & 1640.1 & 1843.5 & 14.12 \\
\hline CV (\%) & 16.6 & 15.46 & 899.6 \\
\hline LSD0.05 & 1852 & 1814 & \\
\hline
\end{tabular}

Source: [31], CV: Coefficient of variation, LSD: Least significant difference.

Maize grain yield response to integrated use of green manure with FYM and NP fertilizer: Integrated use of improved fallow of mucuna [Mucuna pruriens (L) DC] with NP fertilizers significantly improved maize grain yield over the control and recommended rate of inorganic fertilizers at Bako (Table 9). The sole use of IF increased maize grain yield by 75, 56 and 244\% in 2001, 2002 and 2003 cropping seasons, respectively, over the control treatment. The three years average maize grain yield showed that IF alone doubled the yield as compared with the control treatment. fertilizer on plant height and maize grain yield at Bako.
Supplementing the IF with low doses of NP fertilizers or FYM also further increased grain yield. The lowest grain yield was recorded from the control treatment followed by recommended NP fertilizers (Wakene et al. 2007).Therefore, short fallowing of mucuna along with FYM or with low dose of NP fertilizers may be used as low cost intermediate technology for enhancing soil fertility and increased maize yield and also guarantee sustainable maize production in western Ethiopia.

Table 9: Effects of integrated management of mucuna fallow with NP

\begin{tabular}{|c|c|c|c|c|c|c|c|c|}
\hline \multirow{2}{*}{ Treatment } & \multicolumn{4}{|c|}{ Plant Height (cm) } & \multicolumn{4}{|c|}{ Grain Yield ( $t$ ha $^{-1}$ ) } \\
\hline & 2001 & 2002 & 2003 & Mean & 2001 & 2002 & 2003 & Mean \\
\hline Control & 250 & 277 & 201 & 242 & 2.29 & 2.72 & 1.72 & 2.24 \\
\hline IF & 295 & 312 & 248 & 285 & 4 & 4.31 & 5.92 & 4.74 \\
\hline $\mathrm{IF}+55 / 10 \mathrm{NP}$ & 347 & 304 & 269 & 311 & 7.89 & 4.01 & 5.84 & 5.91 \\
\hline $\mathrm{IF}+37 / 7 \mathrm{NP}$ & 339 & 319 & 248 & 297 & 7.66 & 3.81 & 5.87 & 5.78 \\
\hline $\mathrm{IF}+4 \mathrm{tha}^{-1} \mathrm{FYM}$ & 340 & 317 & 274 & 312 & 7.42 & 4.91 & 6.39 & 6.25 \\
\hline $\mathrm{IF}+2.7 \mathrm{tha}^{-1} \mathrm{FYM}$ & 341 & 318 & 270 & 309 & 6.31 & 4.25 & 7.32 & 6.06 \\
\hline $110 / 20 \mathrm{~kg} \mathrm{~h}^{-1} \mathrm{NP}$ & 336 & 318 & 251 & 301 & 5.52 & 3.25 & 4.45 & 4.41 \\
\hline LSD & 39.25 & Ns & 34.76 & 18.86 & 1.37 & NS & 1.81 & 0.85 \\
\hline
\end{tabular}

Source: [15], IF= improved fallow with mucuna green manure.

Effects of lime, vermicompost and chemical $P$ fertilizer on yield of maize: Field experiments were conducted for two consecutive cropping seasons of 2015 and 2016 to evaluate the effects of lime, VC and chemical P fertilizer on yield and yield components of maize in Ebantu District, Western highlands of Ethiopia. The results of ANOVA showed that, the highest mean grain yield ( $4.87 \mathrm{tha}^{-1}$ ) was recorded in plots treated with $40 \mathrm{~kg} \mathrm{P} \mathrm{ha}^{-1}$ and $2.5 \mathrm{t} \mathrm{VC} \mathrm{ha}^{-1}$ with lime, while the lowest $\left(2.18 \mathrm{tha}^{-1}\right)$ was recorded in 
the control (Table 10). This high discrepancy between the highest and lowest grain yields seems also to be due to synergistic effects of these treatments. From Table 10, it is obvious that liming alone did not increase yield and neither did VC when applied without liming and chemical P fertilizer. But combined use of lime and VC almost doubled the yield compared to the control even without chemical $P$ fertilizer [32]. Also, the effect of chemical P fertilizer was much greater when integrated with lime and VC. The results of the study demonstrated that there was a significant increase in yield and yield components of maize due to the application of vermicompost and mineral $P$ fertilizer with lime over the control. Since maize is a huge feeder of nutrients, application of high dose of mineral $\mathrm{P}$ fertilizer together with good nutrients sources of vermicompost has paramount importance in reclaiming soil acidity and enhancing soil fertility and improving maize yield and yield components.

Table 10: Effects of combination of lime, vermicompost, and mineral P fertilizers on grain yield, above ground dry biomass yield, and harvest index of maize.

\begin{tabular}{|c|c|c|c|c|c|c|c|c|c|c|}
\hline \multirow{3}{*}{$\begin{array}{l}\text { Lime and VC ( } t \\
\text { ha }^{-1} \text { ) }\end{array}$} & & \multicolumn{9}{|c|}{ Yield Parameters } \\
\hline & \multicolumn{9}{|c|}{ Mineral P Fertilizer $\left(\mathrm{kg} \mathrm{ha}^{-1}\right)$} & \\
\hline & \multicolumn{3}{|c|}{ GY $\left(\mathrm{t} \mathrm{ha}^{-1}\right)$} & \multicolumn{3}{|c|}{ AGDBY ( $\left.\mathrm{t} \mathrm{ha} \mathrm{a}^{-1}\right)$} & \multicolumn{3}{|c|}{ HI (\%) } & \\
\hline Lime & vC & $\mathbf{0}$ & 20 & 40 & $\mathbf{0}$ & 20 & 40 & $\mathbf{0}$ & 20 & 40 \\
\hline- & 0 & $2.18 \mathrm{~g}$ & $2.36 \mathrm{~g}$ & $3.05 \mathrm{e}$ & $16.1 \mathrm{~g}$ & $16.5 \mathrm{~g}$ & $16.8 \mathrm{fg}$ & $13.6 \mathrm{i}$ & 14.4hi & $16.9 \mathrm{ef}$ \\
\hline 0 & 2.5 & $2.30 \mathrm{~g}$ & $3.03 \mathrm{e}$ & $3.95 \mathrm{~d}$ & $16.3 \mathrm{~g}$ & 17.0efg & $18.4 \mathrm{de}$ & 14.3hi & $17.9 \mathrm{ef}$ & $21.5 \mathrm{bc}$ \\
\hline- & 5 & $2.36 \mathrm{~g}$ & $4.25 c$ & $4.03 \mathrm{~d}$ & $16.5 \mathrm{~g}$ & $18.6 \mathrm{cde}$ & $18.7 \mathrm{~cd}$ & $14.5 \mathrm{ghi}$ & $23.0 \mathrm{ab}$ & $21.5 \mathrm{bc}$ \\
\hline- & 0 & $2.20 \mathrm{~g}$ & $2.77 \mathrm{f}$ & $2.94 \mathrm{ef}$ & $16.5 \mathrm{~g}$ & 17.1efg & $18.2 \mathrm{def}$ & $13.4 \mathrm{i}$ & $16.3 \mathrm{fg}$ & $16.2 \mathrm{fgh}$ \\
\hline 4 & 2.5 & $3.13 \mathrm{e}$ & $4.07 \mathrm{~cd}$ & $4.87 \mathrm{a}$ & 17.1efg & $18.5 \mathrm{cde}$ & $20.0 \mathrm{c}$ & 18.3de & $22.0 \mathrm{~b}$ & $24.4 \mathrm{a}$ \\
\hline- & 5 & $4.02 \mathrm{~d}$ & $4.55 \mathrm{~b}$ & $4.73 \mathrm{ab}$ & 18.3def & $22.7 \mathrm{~b}$ & $25.9 \mathrm{a}$ & $22.0 \mathrm{bc}$ & $20.1 \mathrm{~cd}$ & $18.3 \mathrm{de}$ \\
\hline CV (\%) & - & - & 5.52 & - & - & 7.4 & - & - & 9.01 & - \\
\hline F-test & - & - & $* * *$ & - & - & $*$ & - & - & $* * *$ & - \\
\hline $\mathrm{SE}( \pm)$ & - & - & 0.08 & - & - & 0.55 & - & - & 0.67 & - \\
\hline
\end{tabular}

Source: [32]. Means sharing the same letter(s) are not significantly different according to DMRT at $5 \%$ level of significance. *and ${ }^{* * *}$ indicate significance at $\mathrm{P} \leq 0.5$ and 0.001 , respectively. $\mathrm{VC}=$ Vermicompost; $\mathrm{GY}=$ Grain yield; $\mathrm{AGDBY}=$ Above ground dry biomass yield; $\mathrm{HI}=\mathrm{Harvest}$ index; $\mathrm{CV}$ $=$ Coefficient of variation; SE $=$ Standard Error.

\section{Effect of Cropping System on Maize Productivity}

\section{Cereal-legume intercropping}

Intercropping maize-climbing bean experiment was conducted from 2000 to 2003 cropping seasons at Bako Agricultural research Center (BARC) to determine the effects of inorganic and organic fertilizers on grain yield of maize (Zea mays)- climbing bean (Phaseolus vulgaris) intercropping system. The result of the study showed that Mean grain yield of maize was non-significantly ( $p>0.05$ ) affected by N by P, N by FYM and P by FYM interaction in intercropping system. Three-way interaction of $\mathrm{N}$ by $\mathrm{P}$ by FYM compared to sole and intercropped with recommended rate significantly $(\mathrm{P}<0.05)$ affected mean grain yield of maize (Table 11). This study revealed that intercropping was more productive in terms yield production per unit area and combined yields than mono cropping. Intercropping system maize-climbing bean with higher fertilizer combinations applications produce higher grain yield of both crop [33]. In terms of integrating cropping sequence with NP and FYM, studies show that intercropping of maize with climbing bean with integrated application of $69 / 10 \mathrm{~kg} \mathrm{NP} \mathrm{ha}^{-1}$ with 4-8 t FYM ha-1 gave better grain yields and is recommended for sustainable production of component crops [34].
Table 11: Effects of N-P and FYM on plant height, 1000 seed weight and grain yield of maize in intercropping system.

\begin{tabular}{|c|c|c|c|}
\hline \multirow{2}{*}{ Treatment } & \multicolumn{2}{|c|}{ Grain Yield (kg ha-1) } & \multirow{2}{*}{ LER } \\
\cline { 1 - 3 } N (kg ha-1) & Climbing Bean & Maize & \\
\hline 46 & 1300 & 5581 & 1.29 \\
\hline 69 & 1374 & 5943 & 1.4 \\
\hline LSD (5\%) & Ns & Ns & 0.0958 \\
\hline \multicolumn{4}{|c|}{ P (kg ha-1) } \\
\hline 10 & 1307 & 5918 & 1.36 \\
\hline 20 & 1367 & 5606 & 1.34 \\
\hline LSD (5\%) & Ns & Ns & Ns \\
\hline \multicolumn{4}{|c|}{ FYM (t ha-1) } \\
\hline 4 & 1300 & 5699 & 1.32 \\
\hline 8 & 1374 & 5825 & 1.38 \\
\hline LSD (5\%) & Ns & Ns & Ns \\
\hline Mean & 1337 & 5762 & 1.35 \\
\hline CV $\%$ & 12.38 & 19.89 & 14.95 \\
\hline
\end{tabular}

Source: [27]. Ns= Non-significant at $5 \%$ probability level. 
Another study comprising two sets of experiment was conducted for five consecutive years at Bako Agricultural Research Center to examine the Advantages of intercropping Pigeon Pea used as Live Stake for Climbing Bean (Cajanas Cajan) in Maize Based Cropping Systems with specific objective of evaluating yield performance of maize on residual effect of pigeon pea under different levels of canopy managements with some additional nitrogen $(\mathrm{N})$ application. Combined analysis of variance over years revealed that $\mathrm{N}$ application rates showed a significant effect on maize yield whereas types of crops used during pigeon pea establishment and percentage of branch removal and then retention on the plot and their interaction effects did not show significant differences [35]. Highly significant variation in maize yield was also observed due to variation in cropping season.

Similar experiment was carried out in the same center during 2013, 2014 and 2015 main cropping seasons consisting treatments of maize pigeon pea intercropping in factorial combinations of four pigeon pea branch removals while leaving the upper (0. 2 . 4 and 6) and five nitrogen levels (18. 41. 64. 87 and $110 \mathrm{~kg} \mathrm{~h} \mathrm{a}^{\prime}$ ) and sole maize and pigeon monoculture laid out in Randomized Complete Block Design with three replications. Maize mean grain yield obtained from maize/pigeon pea intercropping regardless of pruning options resulted in $6 \%$ yield advantage over maize grown sole during the initial establishment of pigeon pea (Table 12). With respect to the overall maize grain yield, $1.25 \%$ yield advantage was recorded from maize pigeon pea intercropping [36].

Table 12: Maize biomass and grain yield as affected by the main effects of pigeon pea branch removal and $\mathrm{N}$ level in maize/pigeon pea intercropping at Bako.

\begin{tabular}{|c|c|c|c|c|c|c|}
\hline Factor & \multicolumn{3}{|c|}{ Biomass Weight kg ha' } & \multicolumn{3}{|c|}{ Grain Yield kg ha' } \\
\hline Pigeon Pea Branch Removal Leaving Upper & 2013 & 2014 & 2015 & 2013 & 2014 & 2015 \\
\hline 0 & $24677 a$ & 225013 & 19547 & $9987 a$ & $8602 a$ & $8232 "$ \\
\hline 2 & 23822ah & $21347 a b$ & 19616 & $9822 \mathrm{a}$ & $8569 \mathrm{a}$ & $8260 a$ \\
\hline 4 & 23189ab & $20054 \mathrm{bc}$ & 19891 & 9523ab & $7933 b$ & $7897 \mathrm{ab}$ \\
\hline 6 & $22646 "$ & $19376 \mathrm{c}$ & 20031 & $901 \mathrm{lb}$ & $76581^{\prime}$ & $7429 \mathrm{~b}$ \\
\hline SE \pm & 637 & 210 & 547 & 456 & 109 & 221 \\
\hline $\operatorname{LSD}(5 \%)$ & 1819 & 1303 & NS & 599 & 312 & 632 \\
\hline Sole maize & 22411 & 18767 & 21363 & 9040 & 8193 & 8179 \\
\hline \multicolumn{7}{|c|}{ N Level kg ha'1 } \\
\hline 18 & $21749 \mathrm{~b}$ & 18783b & $17017 \mathrm{C}$ & $8426 \mathrm{~h}$ & $7015 \mathrm{C}$ & $6819 \mathrm{C}$ \\
\hline 41 & $24124^{\circ}$ & 20959a & $17953 c$ & $9017 \mathrm{~b}$ & $8243 b$ & $7158^{\circ}$ \\
\hline 64 & $23654 a b$ & $20827^{\prime \prime}$ & $2004 \mathrm{l} \mathrm{b}$ & 10071" & $8145 b$ & $8132 b$ \\
\hline 87 & $24366^{\prime \prime}$ & $21623^{\prime \prime}$ & $21340 \mathrm{ab}$ & $10205^{\circ}$ & $8730^{\prime \prime}$ & $8671 \mathrm{ab}$ \\
\hline 110 & $2406^{\prime \prime}$ & 21907“ & $22505 \mathrm{~s}$ & $10209 "$ & 8818" & $8995 "$ \\
\hline $\mathrm{SE} \pm$ & 712 & 234 & 612 & 510 & 122 & 247 \\
\hline C V \% & 10.45 & 8.49 & 10.78 & 8.47 & 5.17 & 10.72 \\
\hline LSD 5\% & 2034 & 1457 & 1750 & 669 & 349 & 707 \\
\hline
\end{tabular}

Source: [36].

\section{Cereal-legume/oil crop rotation in maize system}

A study conducted at Bako using nug as proceeding crop indicted that maize grain yields were significantly increased in rotation with this crop compared to the continuous cropped maize. This result clearly demonstrated the residual benefits of crop rotation with reduced NP fertilizer amendments and enhanced maize grain yield. Also, the integrated use of precursor crops with low rate of NP and farmyard manure gave comparable maize yield to a plot received recommended fertilizer rate $\left(110 / 20 \mathrm{~kg} \mathrm{NP} \mathrm{ha}^{-1}\right)$. Production of maize following nug as a precursor crop by integrating with $46 / 5$ $\mathrm{kg} \mathrm{ha}^{-1} \mathrm{NP}$ and 8t FYM ha-1 could be affordable for smallholder farmers in Bako areas. Similarly, improved grain yield of maize was obtained from maize planted with application of half and full recommended rate of nitrogen fertilizer following soil incorporated soybean and faba bean precursor crop biomass, highlighting the importance of additional nitrogen application in the cropping sequence [37]. Accordingly, maize following Niger seed and haricot bean with recommended NP fertilizer application is recommended for enhanced maize production in Bako area. The production of maize following Niger seed precursor crop with 46/5 Kg N-P and 8 t FYM ha $^{-1}$ or recommended fertilizer $(110 / 20 \mathrm{Kg} \mathrm{N-P} \mathrm{ha-1)}$ is recommended for Bako area $[24,38]$. The production of maize following sole haricot bean with the recommended fertilizer rate gave higher mean grain yield and is recommended for sustainable production of maize in the region [38]. 
A crop rotation study on maize rotated with soybean in four districts of Jimma zone showed 26-46\% increments of maize grain yield whenever rotated on previous soybean field (Table 13). It was also further notified that soybean contributed $46 \mathrm{~kg}$ urea- $\mathrm{N}$ ha-1 to succeeding maize and thus, it could offset the cost of $46 \mathrm{~kg}$ urea-N $\mathrm{ha}^{-1}$ for smallholder farmers [39].

Another trial on rotation of common bean in sole and intercropping systems with maize at Bako demonstrated that maize planted following sole planted common bean gave higher mean grain yield and found economically profitable as compared to maize produced following intercropped haricot bean or continuous maize (Table 14). Therefore, maize production following sole common bean with recommended fertilizer could be another alternative for sustainable maize production in Bako areas [40-42].

Table 13: Soybean rotation effects on subsequent maize grain yield.

\begin{tabular}{|c|c|c|c|c|}
\hline \multirow{2}{*}{ Crops in Rotation* + N-Levels } & \multicolumn{2}{|c|}{ Seasons } & \multirow{2}{*}{ Rotation Mean } & \multirow{2}{*}{$\%$ Increase } \\
\hline & 2003 & 2004 & & \\
\hline \multicolumn{5}{|c|}{ Maize Grain Yield in $\mathrm{kg} \mathrm{ha}^{-1}$} \\
\hline $\mathrm{CMZF}+18 \mathrm{~kg} \mathrm{~N}$ ha $^{-1}$ & 3013 & 4693 & $3853 c$ & \\
\hline $\mathrm{CMZF}+64 \mathrm{~kg} \mathrm{~N} \mathrm{ha}^{-1}$ & 4077 & 5628 & $4852 b$ & 26 \\
\hline PSYF + $18 \mathrm{~kg} \mathrm{~N} \mathrm{ha}^{-1}$ & 4417 & 5298 & $4857 \mathrm{~b}$ & 26 \\
\hline PSYF + $64 \mathrm{~kg} \mathrm{~N} \mathrm{ha}^{-1}$ & 5109 & 6185 & $5647 a$ & 46 \\
\hline Season-mean & $4154 b$ & $5451 \mathrm{a}$ & & \\
\hline
\end{tabular}

Table 14: Effects of common bean rotations and N/P fertilizer rate on grain yield of succeeded maize.

\begin{tabular}{|c|c|c|c|c|}
\hline \multicolumn{2}{|c|}{ Treatment } & \multicolumn{3}{|c|}{ Grain Yield (kg ha-1) } \\
\hline Crops (2004) & Maize with $\mathrm{N} / \mathrm{P}_{2} \mathrm{O}_{5} \mathrm{~kg} \mathrm{ha}^{-1}$ & 2005 & 2006 & Mean \\
\hline $\mathrm{M} / \mathrm{BB}$ & $M-59 / 23$ & 5950 & 4254 & 5102 \\
\hline $\mathrm{M} / \mathrm{BB}$ & M-89/35 & 6484 & 3897 & 5191 \\
\hline $\mathrm{M} / \mathrm{BB}$ & M-110/46 & 6935 & 5777 & 6356 \\
\hline BB & $M-59 / 23$ & 8691 & 5872 & 7281 \\
\hline BB & M-89/35 & 8571 & 5841 & 7206 \\
\hline $\mathrm{BB}$ & M - $110 / 46$ & 9550 & 6052 & 7801 \\
\hline $\mathrm{M} / \mathrm{CB}$ & M- 59/23 & 5055 & 4429 & 4742 \\
\hline $\mathrm{M} / \mathrm{CB}$ & M- 89/35 & 6278 & 5508 & 5893 \\
\hline $\mathrm{M} / \mathrm{CB}$ & M- $110 / 46$ & 7797 & 5686 & 6742 \\
\hline СB & M- 59/23 & 8457 & 4517 & 6487 \\
\hline СB & M- 89/35 & 9240 & 5733 & 7486 \\
\hline СB & M - $110 / 46$ & 10148 & 6066 & 8107 \\
\hline M & M - $110 / 46$ & 7314 & 6123 & 6718 \\
\hline $\mathrm{LSD}<0.05$ & & 2374 & 1879 & 1484 \\
\hline
\end{tabular}

Source: [41], $\mathrm{M} / \mathrm{BB}=$ maize/bush bean intercropping, $\mathrm{BB}=$ sole bush bean, $\mathrm{M} / \mathrm{CB}=$ maize/climbing bean intercropping, $\mathrm{CB}=$ sole climbing bean, $\mathrm{M}$ = sole maize.

\section{Conclusion}

Soil fertility decline that includes nutrient depletion, nutrient mining, acidification, the loss of Organic Matter (OM) and others, and poor cropping system have stayed to be the major factors causing hindrance to maize production in Ethiopia. In an attempt of counteracting and alleviating this problem in the country and to offer low input technology on soil fertilization, various research endeavours aiming at boosting the productivity of maize related to Soil property changes in a positive direction under use of different organic and inorganic fertilizer sources and improved cropping system had been made in different parts of Ethiopia by researchers and scholars from Agricultural Research Institutions found in the country. The findings of the reviewed research outputs of these efforts reveal that there is potential for increasing crop productivity through improved and available soil fertility management practices and cropping system.

The results of study conducted at Bako revealed that green manuring provided comparable grain yield to that of the 
recommended NP fertilizers on marginal soil fertility status. Similarly, green manure of sole legumes could substitute for more than $70 \mathrm{~kg}$ urea $\mathrm{N} \mathrm{ha}^{-1}$ at Jimma. The analysis suggests that amending legume fallows and green manuring with mineral fertilizer may be important if high yield productivity must be sustained over several years, as yields normally fall as the post fallow cropping period lengthen. An experiment conducted in Bako concluded that use of $12 \mathrm{t} \mathrm{ha}^{-1}$ of FYM with 28/12 NP205 $\mathrm{kg} \mathrm{ha}^{-1}$ saved up to $75 \%$ cost of commercial fertilizer. Another field experiment done in Western Oromiya, application of $150 / 50 \mathrm{~kg} \mathrm{ha}^{-1}$ of Urea and DAP with $4 \mathrm{t}$ FYM ha-1 was recommended for sustainable production of maize. The findings of similar study in Borena indicated that crop yield from the nutrient-poor soils of the region can be substantially enhanced by using manure, despite the traditional beliefs linking manure use to misfortune in the area. Use of five tons ha-1 of compost with $55 / 10 \mathrm{~kg}$ of N/P ha ${ }^{-1}$ is found economical for maize production in Bako Tibe district and other similar areas in western regions. Another trial proceeded at acidic nitosol of Southwestern Ethiopia concluded that application of 50\% recommended NP and $50 \%$ compost gave the highest grain yield. A work done at Ebantu district, showed that integrated use of vermicompost at $\left(2.5 \mathrm{tha}^{-1}\right)$ and mineral P $\left(20 \mathrm{~kg} \mathrm{ha}^{-1}\right)$ with lime $\left(4 \mathrm{tha}^{-1}\right)$ was recommended for reclaiming soil acidity and improve nutrients for maize. Hence, organic fertilizers can be applied with chemical fertilizers in organic carbon depleted arable soils to improve soil properties and crop productivity. Also, the combined use of organic and inorganic fertilizers has a positive synergy that can reduce the chemical fertilizer cost as well as mitigate the environmental hazardous effect.

Intercropping of maize with climbing bean within the same row at $10 \mathrm{~cm}$ distance between maize and climbing bean with 150/50 $\mathrm{kg} \mathrm{ha}^{-1}$ Urea /DAP and $4 \mathrm{t}$ FYM ha-1 fertilizer combinations is recommended for sustainable production of component crops at Bako. Similarly, the buildup of soil fertility through establishing pigeon pea and its biomass retention evidently boost the productivity of the soil and even $100 \%$ reduction of chemical $\mathrm{N}$ fertilizer cost for maize production. Maize sown in rotation with nug and soybean at Bako and Jimma, respectively required one-half of the recommended fertilizer rates that crop rotations offset $50 \%$ of fertilizer cost. The production of maize following sole haricot bean with the recommended fertilizer rate gave higher mean grain yield and is recommended for sustainable production of maize in Bako area. Therefore, potential grain legumes and forage and fodder legumes should better be intercropped and utilized in rotation with maize to enhance soil fertility and boost grain yield at low cost for maize based farming system in Ethiopia.

\section{Acknowledgement}

None.

\section{Conflict of Interest}

No conflict of interest.

\section{References}

1. Ashraf U, Abbas RN, Hussain S, Mo ZW, Anjum SA, et al. (2016b) Consequences of varied planting geometry and early post emergence herbicides for crop-weed interventions in rice under semi-arid climate. Planta Daninha 34(4): 737-746.

2. Martin JH, Waldren RP, Stamp DL (2006) Principles of field crop production. Pearson Education, USA.

3. FAO (2011) Missing food: The Case of Postharvest Grain Losses in SubSaharan Africa.

4. Legesse W, Mosisa W, Berhanu T, Girume A, Wende A, et al. (2011) Genetic Improvement of Maize for Mid-Altitude and Low land sub-Humid AgroEcologies of Ethiopia. In: W Mosisa, S Twumasi A, W Legesse, T Berhanu, W Dagne, BM Prasanna (eds.), Meeting the Challenges of Global Climate Change and Food Security through Innovative Maize Research Proceedings of the $3^{\text {rd }}$ National Maize workshop of Ethiopia, pp. 18-20.

5. CSA (2010) Reports on area and crop product on forecasts for major grain crops (For private peasant holding, Meher Season). The FDRE Statistical Bulletins, Ethiopia.

6. FAO (2008) Food and Agriculture Organization of the United Nations statistical database.

7. Kebede M, Gezahgne B, Benti T, Mosisa W, Yigzaw D, et al. (1993) Maize production trends and research in Ethiopia. Paper presented at the 1. National Maize Workshop of Ethiopia, Addis Abeba (Ethiopia), pp. 52.

8. Mc Cann JC (1995) The plow in the forest: Agriculture, population and maize monocuture in Gera. In: People of the plow: an agricultural history of Ethiopia, pp. 147-190.

9. Thorne PJ, Thornton PK, Kruska PL, Reynolds L, Waddington SR, et al. (2002) Maize as food feed and fertilizer in intensifying Crop-livestock systems in East and southern Africa: An ex-ante impact assessment of technology intervention to improve smallholder welfare. ILRI, impact Journal of Resources Development and Management www.iiste.org ISSN 2422-8397 An International Peer-reviewed Journal 23: 13-19.

10. CIMMYT (1999) Maize Production Technology for the Future: Challenges and Opportunities. Proceedings of the Sixth Eastern and Southern Africa Regional Maize Conference, Ethiopia: CIMMYT (international maize and wheat improvement center), pp. 21-25.

11. Smaling EMA, Nandwa SM, Janssen BH (1997) Soil fertility in Africa is at stake. In: Buresh RJ, Sanchez PA, Calhoun F (Eds.). Replenishing Soil Fertility in Africa. Soil Science Society of America 51: 47-61.

12. Sanchez PA (1995) Multiple cropping: An appraisal of present Knowledge and future needs. Proceedings of multiple cropping symposium, American society of Agronomy Annual Meeting. Knocville, Tennessee, pp. 24-28.

13. Zhao Y, Wang P, Li J, Chen Y, Ying X, Liu S (2009) The effects of two organic manures on soil properties and crop yields on a temperate calcareous soil under a wheat-maize cropping system. Eur J Agron 31: 36-42.

14. Abbasi, MK, Yousra M (2012) Synergestic effects of biofertilizer with organic and chemical $\mathrm{N}$ sources in improving soil nutrient status and increasing growth and yield of wheat grown under greenhouse conditions. Plant biosystems 146: 181-189.

15. Wakene N, Fite G, Abdena D, Berhanu D (2007) Integrated Use of Organic and Inorganic Fertilizers for Maize Production In: Utilization of Diversity in land use systems: Sustainale and organic approaches to meet human needs. Conference Tropentag, Germany, pp. 9-12.

16. Tadesse Yohannes, Tolessa Debele (1998) Cultural practices, cropping systems and fertility studies on maize production in Eastern, western Wollaga and Assosa. In: Beyene Seboka and Aberra Deressa (eds.). Agricultural Research and Technology Transfer Attempts and Achievement in Western Ethiopia. Proceedings of the Third Technology Generation, Transfer and Gap Analysis Workshop, Ethiopia, pp. 133-139.

17. Egbe OM, Alibo SE, Nwueze I (2010) Evaluation of some extra-earlyand early- maturing cowpea varieties for intercropping with maize in southern guinea savannah of Nigeria. Agriculture and Biology Journal of North America 1(5): 845-858. 
18. Negassa W, Getaneh F, Deressa A, Dinsa B (2007) Integrated use of organic and inorganic fertilizers for maize production. Utilization of diversity in land use systems: Sustainable and organic approaches to meet human needs. A paper presented on Tropentag, pp. 9-11.

19. Habtamu Admas (2015) Response of maize (Zea mays L.) to different levels of nitrogen and sulfur fertilizers in Chilga District, Amhara National Regional State, Ethiopia. Basic Research Journal of Soil and Environmental Science 3(3): 38-49.

20. Zelalem Bekeko (2013) Effect of nitrogen and phosphorus fertilizers on some soil properties and grain yield of maize (BH-140) at Chiro, Western Hararghe, Ethiopia. African Journal of Agricultural Research 8(45): 5693-5698.

21. Hassen Abdulahi, Sarobol ED, Vichukit V, Suwannarat C (2006) Uptake and Response of Maize (Zea mays L.) Varieties to Nitrogen and Phosphorus Fertilizers in Semi-arid Areas of Eastern Ethiopia. Kasetsart Journal (Natural Sciences.) 40: 604-615.

22. Wassie Haile, Shiferaw Boke, Kelsa Kena (2009) Integrated Soil Fertility Management Options for Sustainable Crop Production: Review of Research Findings from Southern Regional State of Ethiopia. In: Improved natural resource management technologies for food security, poverty reduction and sustainable development. Proceedings of the 10th Conference of the Ethiopian Society of Soil Science, Ethiopia. pp 163-175.

23. Tadele Amare, Tesfaye Feyisa, Yihenew G Selasie (2010) Response of Maize, Malt Barley and Tomato to Potassium. In: Birru Yitaferu, Teshome Tesema, Zewudu Ayalew (Eds). Proceedings of the 3rd Annual Regional Conference on Completed Research Activities on Soil and Water Management, Forestry, and Agricultural Mechanization, Amhara Region Agricultural Research Institute (ARARI), Ethiopia. Pp. 67-75.

24. Tesfa Bogale, Tolera Abera, Tewodros Mesfin, Gebresilasie Hailu, Temesgen Desalegn, et al. (2012) Review on Crop Management Research for Improved Maize Productivity in Ethiopia. In: Worku M, Twumasi Afriyie S, Wolde L, Tadesse B, Demisie G, et al. (Eds.) 2012. Meeting the Challenges of Global Climate Change and Food Security through Innovative Maize Research. Proceedings of the Third National Maize Workshop of Ethiopia. Mexico.

25. Yonas Jagisso, Jens Aune, Ayana Angassa (2019) Unlocking the Agricultural Potential of Manure in Agropastoral Systems: Traditional Beliefs Hindering Its Use in Southern Ethiopia. Pp. 9: 45.

26. Tolessa D (1999) Effects of organic and inorganic fertilizers on maize grain yield in western Ethiopia. In: Proceeding of the African Crop Science, Conference 4: 229-102.

27. Negassa W, Kefalew Negisho, Friesen DK, Ransom J, Abebe Yadessa (2004) Determination of optimum Farmyard manure and NP fertilizers for maize on farmer's fields. In: Friesen DK and Palmer AFE. (eds.). Integrated Approaches to higher maize productivity in the new millennium: Proceedings of the Seventh Eastern and Southern African Regional Maize Conference, Kenya: CIMMYT, pp. 387-393.

28. Tolera A, Daba F, Hasan Y, Olani N, Al Tawaha AR (2005) Grain yield of maize as affected by biogas slurry and NP fertilizer rate at Bako, Western Oromia, Ethiopia. Bioscience Research 2(1): 31-37.

29. Heluf G, Asfaw B, Yohannes, Eylachew Z (1999) Yield response of maize (Zea mays L.) to crop residue management on two major soil types of Alemaya, Eastern Ethiopia: I. Effects of Varying Rates of Applied and Residual N and P Fertilizers. Nutrient Cycling in Agroecosystems 54: 6571.
30. Tenaw W (2006) Effect of coffee residue and cropping system on crop yield and physico-chemical properties of the soil in southern Ethiopia.

31. Solomon Endris and Jafer Dawid (2015) Yield Response of Maize to Integrated Soil Fertility Management on Acidic Nitosol of Southwestern Ethiopia. Journal of Agronomy 14(3): 152-157.

32. Abdissa Bekele, Kibebew Kibret, Bobe Bedadi, Tesfaye Balemi, Markku Yli Halla (2018) Effects of lime, vermicompost and chemical P fertilizer on yield of maize in Ebantu District, Western highlands of Ethiopia. African Journal of Agricultural Research 13(10): 477-489.

33. Tolera Abera, Daba Feyissa and Hasan Yusuf (2005). Effects of Inorganic and Organic Fertilizers on Grain Yield of Maize-Climbing Bean Intercropping and Soil Fertility in Western Oromiya, Ethiopia. Conference on International Agricultural Research for Development, Germany, pp. 11-13.

34. Tolera Abera (2012) NP fertilizer rate response of maize and sorghum succeeding sole or intercropped haricot beans. In: Tusiime G, Majaliwa Mwanjololo JG, Nampala P, Adipala E. (Eds.). Proceedings of the Third RUFORUM Biennial Regional Conference on Partnerships and Networking for Strengthening Agricultural Innovation and Higher Education in Africa, Uganda. Pp. 1851-1862.

35. Zerihun Abebe, Shiferaw Tadesse and Meseret Tola (2016) Multiple Advantages of Pigeon Pea (Cajanas Cajan) in Maize Based Cropping Systems: Used as Live Stake for Climbing Bean with Phosphorus Rates and Maize Productivity Enhancement in Mono Cropping Areas. Journal of Natural Sciences Research 6: 19.

36. Shiferaw Tadesse', Zerihun Abebe and Lema Teklu (2017) Soil Chemical Properties and Crop Productivity as Influenced by Pruning Options of Pigeon Pea and N R ate on Maize in Cereal-Legume Integrated Cropping System at Bako. Proceedings of Review Workshop on Completed Research Activities of Natural Resource Directorate held at Adami Tulu Agricultural Research Center, Ethiopia, pp. 4-6.

37. Tolera Abera (2016) Effects of soil incorporated faba bean and soybean biomass on yields of subsequent maize in western Ethiopia. PhD dissertation. Sokoine University of Agriculture, Morogoro, Tanzania, pp. 168.

38. Tolera A, Daba F, Friesen D K (2009) Effects of Crop rotation and N-P Fertilizer Rate on Grain Yield and related characteristics of Maize and Soil Fertility at Bako Western Oromia, Ethiopia. East African Journal of Science 3(1): 70-79.

39. Tesfa B, Kaleb A, Terefe F, Gebresilassie H (2009) Integration of Soybean for Crop Rotation in Maize Based Farming System. $12^{\text {th }}$ Crop science society of Ethiopia, CSSE, Ethiopia.

40. Wakene N, Tolera A, Friesen DK, Abdenna D, Berhanu D (2004) Evaluation compost for maize production under farmers' conditions. In: Friesen DK, Palmer AFE (Eds.). Integrated Approaches to higher maize productivity in the new millennium: Proceedings of the Seventh Eastern and Southern African Regional Maize Conference, Kenya: CIMMYT. (International Maize and Wheat Improvement Center) and KARI (Kenya Agricultural Research Institute), pp. 5-11.

41. Anonymous (2004-2007) Progress Report of Bako Agricultural Research Center. Agronomy and Crop Physiology Research Division. Malaysia.

42. FAO (1999) Fertilizer Strategies. International Fertilizer Industry Association. FAO (Food and Agriculture Organization), 2000. Fertilizer and their use. A pocket guide for extension officers. ( $\left.4^{\text {th }} \mathrm{edn}\right)$, Italy, pp. 98. 